\title{
Earth system governance: a research framework
}

\author{
Frank Biermann • Michele M. Betsill • Joyeeta Gupta \\ Norichika Kanie • Louis Lebel • Diana Liverman • Heike Schroeder • \\ Bernd Siebenhüner • Ruben Zondervan
}

Accepted: 1 February 2010/Published online: 8 October 2010

(C) The Author(s) 2010. This article is published with open access at Springerlink.com

\begin{abstract}
The Earth System Science Partnership, which unites all major global change research programmes, declared in 2001 an urgent need to develop "strategies for Earth System management". Yet what such strategies might be, how they could be developed, and how effective, efficient and equitable such strategies would be, remains unspecified. It is apparent that the institutions, organizations and mechanisms by which humans currently govern their relationship with the natural environment and global biochemical systems are not only insufficient - they are also poorly understood. This article presents the science programme of the Earth System Governance Project, a new 10-year global research effort
\end{abstract}

F. Biermann $(\bowtie) \cdot$ J. Gupta

Institute for Environmental Studies, Department of Environmental Policy Analysis,

VU University, Amsterdam, The Netherlands

e-mail: frank.biermann@ivm.vu.nl

M. M. Betsill

Colorado State University, Fort Collins, CO, USA

J. Gupta

UNESCO-IHE, Delft, The Netherlands

N. Kanie

Tokyo Institute of Technology, Meguro, Tokyo, Japan

L. Lebel

Unit for Social and Environmental Research, Chiang Mai University, Chiang Mai, Thailand

D. Liverman

University of Arizona, Tucson, AZ, USA

D. Liverman · H. Schroeder

Oxford University, Oxford, United Kingdom

B. Siebenhüner

Oldenburg University, Oldenburg, Germany

F. Biermann · R. Zondervan

Earth System Governance Project, International Project Office, Lund University, Lund, Sweden 
endorsed by the International Human Dimensions Programme on Global Environmental Change (IHDP). It outlines the concept of earth system governance as a challenge for the social sciences, and it elaborates on the interlinked analytical problems and research questions of earth system governance as an object of study. These analytical problems concern the overall architecture of earth system governance, agency beyond the state and of the state, the adaptiveness of governance mechanisms and processes as well as their accountability and legitimacy, and modes of allocation and access in earth system governance. The article also outlines four crosscutting research themes that are crucial for the study of each analytical problem as well as for the integrated understanding of earth system governance: the role of power, knowledge, norms and scale.

Keywords Accountability - Adaptiveness - Agency - Allocation and access · Architecture - Global governance $\cdot$ Earth system analysis · Earth system governance

\section{Introduction}

The current impacts of human activities on planetary biogeophysical systems have become so pervasive and profound that they could inadvertently alter the Earth system in ways that may prove irreversible (ESSP 2001; Leemans et al. 2009, for a comprehensive scientific treatment see Steffen et al. 2004). This development has become a key challenge for policy-makers at all levels of decision-making, ranging from the need to limit human largescale disturbance in natural biogeophysical cycles to the increasing exigency to preparepolitically, legally, socially and economically-for the adaptation to those global environmental changes that can no longer be halted (Rockström et al. 2009). In recognition, the Earth System Science Partnership ${ }^{1}$ declared an "urgent need" to develop "strategies for Earth System management". Yet what such strategies might be, how they could be developed, and how effective, efficient and equitable such strategies would be, remain unspecified. It is apparent that the institutions, organizations and institutional arrangements by which humans currently govern their relationship with the natural environment and global biochemical systems are not only insufficient: they are also inadequately understood.

This is the rationale for the Earth System Governance Project, a new core project of the International Human Dimensions Programme on Global Environmental Change. The tenyear global initiative aims to bring together researchers from many disciplines and regions to tackle pressing research problems in a coordinated, collaborative effort. This article summarizes the science programme of the Earth System Governance Project (for a full version of the science plan see Biermann et al. 2009a). ${ }^{2}$ First, we outline the concept of earth system governance as a core challenge for the social sciences (Sect. 2). We then elaborate on the interlinked analytical problems and research questions of earth system governance (Sect. 3) and on crosscutting research themes that are crucial for the study of each analytical problem as well as for the integrated understanding of earth system governance (Sect. 4). We finally focus on interlinkages among the analytical problems and

\footnotetext{
1 These four programmes are the integrated programme of biodiversity sciences Diversitas, the International Geosphere-Biosphere Programme, the World Climate Research Programme, and the International Human Dimensions Programme on Global Environmental Change. See www.essp.org.

${ }^{2}$ For more information on the development and implementation of the Earth System Governance Project, see www.earthsystemgovernance.org.
} 
crosscutting themes (Sect. 5) and on the policy relevance of this new global research programme (Sect. 6).

\section{Conceptualizing earth system governance}

Traditional notions of environmental policy, pollution control and nature conservation no longer capture current global developments that transform the biogeophysical cycles and processes of our planet. New perspectives and research are needed to understand the complex relation between global transformations of social and natural systems, including accelerating economic integration, globalization in all its forms, internationalization of policy processes, and the multi-scale consequences of ecological transformation. Innovative research is needed also to analyse political options to govern sustainable development-taking into account not only political effectiveness and efficiency but also global and national justice and equity and the need to bridge levels of analysis and disciplinary assumptions, methods and foci.

One of these new perspectives that we propose here is the concept of 'earth system governance' (developed in more detail in Biermann 2007, 2008). We understand earth system governance as the interrelated and increasingly integrated system of formal and informal rules, rule-making systems, and actor-networks at all levels of human society (from local to global) that are set up to steer societies towards preventing, mitigating, and adapting to global and local environmental change and, in particular, earth system transformation, within the normative context of sustainable development.

Earth system governance stands at the interface of two broad strands of academic inquiry: governance theory and earth system analysis. Governance has been defined in a variety of ways, and there is no consensus among scholars on the core elements of this concept (Van Kersbergen and Van Waarden 2004; Adger and Jordan 2008; Jordan 2008). In most bodies of literature, the term governance denotes new forms of regulation that go beyond traditional hierarchical state activity. It usually implies some form of self-regulation by societal actors, private-public cooperation in the solving of societal problems, and new forms of multilevel policy. At the international level, the term 'global governance' is often used to describe processes of modern world politics, although also here no consensus on the appropriate definition has been reached (Young 1999; Commission on Global Governance 1995; Rosenau 1995; Kanie and Haas 2004; Biermann and Pattberg 2008). The concept of governance is mirrored in legal science, where scholars observe an evolution from an international law based on explicit state consent to an administrative law system with merely implicit state consent (e.g., Kingsbury et al. 2005; Krisch 2006; Brunnée 2002) and from single to pluralist sites and actors of governance (Krisch 2006) and to multilevel systems of governance and complex hybrid public-private international law systems (Sornarajah 2006; Sourgens 2007). Importantly, from the local to international levels, the concept of governance is not confined to states and governments as sole actors, but is marked by participation of myriad public and private non-state actors at all levels of decision-making, ranging from networks of experts, environmentalists and multinational corporations to new agencies set up by governments, such as intergovernmental bureaucracies.

Equally important for the notion of earth system governance is its link to earth system analysis. Especially in the natural sciences that build on quantification and computer-based modelling, efforts have long been underway to combine and integrate models of different strands of research to gain understanding not of isolated elements of global change, but of the totality of processes in nature and human civilization. Research on institutions and 
governance mechanisms is often viewed as part of this integrated effort and is formally included in most theoretical conceptualizations in this field (for example, Schellnhuber 1999, C19-C23). In practice, however, it remains a major research challenge to establish to what extent institutional and governance research can contribute to, and integrate with, the more model-driven research programmes (Biermann 2007). On the one hand, scholars will thus need to continue pursuing research that is interdisciplinary across the social sciences and that follows the internal logic and particular theoretical, epistemological and methodological approaches of the social sciences and the humanities, which are often qualitative, case-based, context-dependent and reflexive. On the other hand, however, it is important and timely to explore also integrated approaches that seek novel ways of incorporating research on governance and institutions in computer-based models and scenarios. The Earth System Governance Project is designed to integrate both communities in a common quest for identifying and analysing governance solutions to cope with the emergent threat of earth system transformation.

\section{Research problems of earth system governance}

The Earth System Governance Project (Biermann et al. 2009a) prioritizes five interdependent analytical problems (Fig. 1). These are the problem of the overall architecture of earth system governance, of agency beyond the state and of the state, of the adaptiveness of governance mechanisms and processes, of their accountability and legitimacy, and of modes of allocation and access in earth system governance (Biermann 2007).

\subsection{The problem of architecture}

The first analytical problem is the overall architecture of systems of earth system governance. So far, most institutional research in this field has focused on single institutions, especially in the international realm of regulation. We now have a better understanding of the creation, maintenance and effectiveness of international environmental regimes and national policies, as well as better methodological tools to study these questions. It has been shown, for example, that different international norms and verification procedures, compliance management systems, modes of regime allocation as well as external factors, such as the structure of the problem, all influence regime effectiveness (Mitchell 2008; Underdal 2008; Breitmeier et al. 2006). Most of these studies have focused on the

Fig. 1 Schematic overview of the Science Plan of the Earth System Governance Project

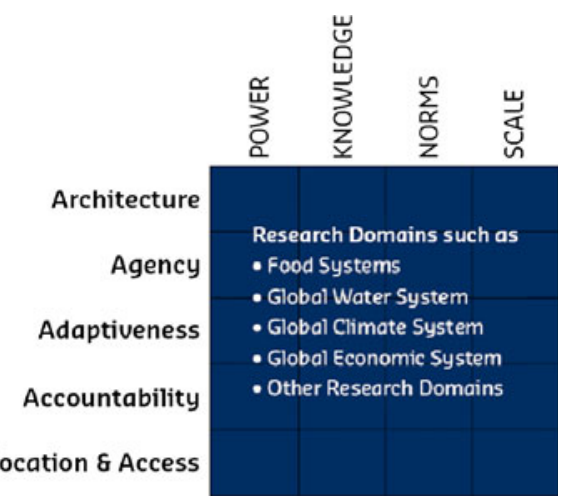


effectiveness of single institutions, often within larger comparative projects. More recently, the increasing number and scope of international environmental institutions has led to new research on their interaction, for example, in studies on regime interlinkages, regime clusters or regime complexes, and broader consequences of regimes (e.g., Chambers 2001; Oberthür and Gehring 2006; Rosendal 2001a, b; Schroeder 2008; Stokke 2000; Underdal and Young 2004). Also at the national and local levels, interactions and interlinkages between different institutions have been a concern for many years, for example in the analysis of (environmental) policy integration or in the analysis of environmental governance in federal systems in which different jurisdictional competences at times overlap (Rabe 2006; Scheberle 2004; VanNijnatten and Boardman 2009).

Such clusters of norms, principles, regimes and other institutions in any issue area can be conceived as its governance architecture (Biermann et al. 2009c). This concept of governance architecture makes it possible to analyse situations in which a governance area is regulated by more than one institution. In such situations, the notion of governance architecture conceptualizes the overarching system of public or private institutions, principles, norms, regulations, decision-making procedures and organizations that are valid or active in the issue area. Architecture can thus be described, in other words, as the metalevel of governance. This meta-level is not to be understood as static entity, but rather as a fluid, dynamic architecture that continuously evolves according to pressures and governance processes. A renewed research effort on governance architectures will continue and expand the current lines of research along a number of questions.

1. First, research on architecture should ask how the performance of environmental institutions is affected by their embeddedness in larger architectures. This includes much work under conceptual headings such as institutional interplay, institutional interaction, institutional complexes, and institutional constellations (Gehring and Oberthür 2008). More work is needed to understand the performance of single environmental institutions within larger architectures, and to understand the performance of entire clusters of institutions.

2. Second, what are the environmental consequences of non-environmental governance systems? This question includes the study of the environmental consequences of institutions that do not cover environmental policy, such as the specific agreements under the world trade regime or bilateral investment treaties (Tienhaara 2006). To the extent that the environmental consequences of non-environmental institutions are covered by environmental institutions at the same time, the problem of nonenvironmental institutions becomes a problem of institutional interaction, and hence a problem of the architecture of environmental governance (see Gehring and Oberthür 2008 on the state of the art in this field).

3. Third, the research theme of architecture entails the analysis of vertical institutional interaction and the role of institutions within multilayered institutional systems. In political science research, this problem is generally understood as the problem of multilevel, or multilayered, governance (Hooghe and Marks 2003; Betsill and Bulkeley 2004; Betsill 2006; Adger 2006b; Cash et al. 2006). Related to this is the analysis of variability in performance of spatial and functional architectures. For instance, certain characteristics that make one type of architecture more effective might be relevant only for spatial architectures, or only for specific functional architectures, such as issuespecific institutions as opposed to geographically defined institutions.

4. Fourth, research on governance architectures will also need to investigate noninstitutions, that is, conflict areas where no effective institutions have been agreed 
upon (for example in the area of deforestation). How can we explain such instances of non-governance? This inquiry addresses the recurrent problem in social science of case selection on the dependent variable, in this case, on the explanation of the emergence and performance of institutions through the analysis only of issue areas where institutions, in fact, have been agreed (see Underdal 2008 in more detail on this problem).

5. Fifth, this analytical problem also covers research into overarching and crosscutting norms of earth system governance. Given the density of the architecture of earth system governance, there is an increasing need to better understand the principles and norms that run through all, or through a large number of, institutions (Bernstein 2001). More generally, this is the problem of identifying constitutional principles and basic norms in earth system governance. The political behaviour of states is guided not merely by calculations of material interest and power, but by international norms that prescribe and prohibit types of behaviour and create an international society that socializes states-including new governments that have not participated in original norm creation (March and Olsen 1998; Barnett and Finnemore 2004). For such norms to be effective, they must be relatively simple, cross-culturally appealing, and sufficiently clear and unambiguous. An example is the development of human rights norms in the course of the twentieth century (Risse et al. 1999). Similar basic norms for earth system governance are emerging, such as the principle of common but differentiated responsibilities. Others are emerging but still disputed, such as the notion of interstate liability in the area of global environmental change, or the principle of prior informed consent. Some of the contested principles at the global level are well accepted and implemented at the local level, which indicates variant values applied domestically and internationally. Identifying and understanding whether universal principles are desirable and acceptable; whether countries and actors are willing to be consistent in applying such principles in different policy and political arenas (on applying norms in climate governance see for example Kanie et al. 2010); and how normative forcing has a critical role in changing behaviour, remain key research challenges.

\subsection{The problem of agency}

The second analytical problem advanced by the Earth System Governance Project is agency. Many vital institutions of earth system governance are today inclusive of, or even driven by, non-state actors from the local to the global level. These often cut across publicprivate divides (Bulkeley and Betsill 2003; Selin and VanDeveer 2005; Pattberg and Stripple 2008). At the international level, actors span the entire spectrum from public nonstate, such as intergovernmental bureaucracies (Biermann and Siebenhüner 2009) or city governments (Betsill and Bulkeley 2004, 2006), to public-private, such as environmentalist alliances (Betsill 2006; Betsill and Corell 2008; Wapner 1996; Dombrowski 2010) or scientific networks (Andresen et al. 2000; Haas 1993), to purely private actors, such as business associations (Haufler 2000; Levy and Newell 2004; Rowlands 2001), and indigenous peoples networks (Schroeder 2010). The activities of non-state actors in earth system governance are not confined to citizen protests, advocacy, lobbying or advising in the creation and implementation of rules. Rather, these actors frequently become agents of earth system governance in that they substantively participate in and/or set their own rules related to the interactions between humans and their natural environment. Private actors 
have joined governments to put norms into practice, and at times they negotiate their own standards, as in the Forest Stewardship Council or the Marine Stewardship Council (Cashore 2002; Pattberg 2005, 2006). Public-private cooperation has received considerable impetus since the 2002 World Summit on Sustainable Development in Johannesburg and its focus on partnerships of governments, non-governmental organizations and the private sector (Andonova and Levy 2003; Glasbergen et al. 2007; Biermann et al. 2007).

As a result, there is a reconfiguration of authority in the realm of governance, making it necessary to distinguish between actors and agents. Actors refer to the individuals, organizations and networks that participate in decision-making related to the earth system. An agent of earth system governance is an actor who possesses the ability to prescribe behaviour and to obtain the consent of the governed. Hence, an agent is an authoritative actor. Authority here is understood as the legitimacy and capacity to exercise power, while power refers merely to the capacity to influence outcomes, with or without the legitimacy to do so. Legitimacy is conferred through social consent, given formally or informally. Whether authority may be claimed unequivocally by an agent is an open question; it is here where the concepts of power and authority blend together. Agents may contribute to the purposeful steering of constituents either indirectly (by influencing the decisions of other actors) or directly (by making steering decisions). They are thus a constituent part of the cumulative steering effort toward preventing, mitigating or adapting to earth system transformation.

Four broad research questions arise, each related to a broader social science debate (Biermann et al. 2009a):

1. First, what is agency in earth system governance? The term 'agency' is widely used across the social sciences and humanities. It could be understood as the capacity to act in the face of global environmental change or to produce effects (positive or negative) that ultimately shape natural processes. It may be useful to consider agency as a dynamic trait that can be created and lost and to explore how this is shaped by environmental change. If agency is dynamic, is it zero-sum in that as some actors gain agency in a policy domain others lose agency? Or can agency be shared across actors?

2. Second, we need to go beyond identifying actors that participate in governance related to the earth system and instead focus on those actors that exercise agency. We need to ask who are the agents of earth system governance? To do so, we need to gain insight into how agency is configured in different policy domains (for an example on climate governance see Dombrowski 2010). Who are the key agents in a particular issue area and how are they related to one another? How is the agency of states reconfigured as non-state actors become agents, especially at local, regional and international levels of governance? How does agency differ from culture to culture, context to context? What broad types of agents are central in the area? How can we advance understanding of what non-state actors are, other than that they are not state actors?

3. Third, how do different agents exercise agency in earth system governance? We can expect that different agents become authoritative on different grounds, so it is important to enquire into the source of authority. Does the source of authority differ across policy domains, levels of governance and political contexts? Research in this area should explore how power and authority are configured in types of governance arrangements as well as the changing nature of state-based power and authority as new actors become agents. This research question also highlights new forms of governance beyond typical state-based institutions. These include markets, certification schemes, self-regulation, public-private partnerships, and transnational networks. There is a 
need to document these various forms of governance through which actors exercise agency and to understand how the process of governing varies across governance architectures. To do so, we need to better understand the conditions for the emergence of agency at different levels and within different architectures.

4. Fourth, the effectiveness of different agents and their various means of exercising agency are insufficiently understood. The question is how can we evaluate the significance of agents and agency? Most advances in the study of international environmental governance have focused on states as core actors and on intergovernmental forms of cooperation. This leads us to ask the following: How can we assess the effectiveness of different agents and their various means of exercising agency? Can we apply approaches developed in the study of institutions, such as output-outcomeimpact, to agency? Can we apply approaches developed in sociology and anthropology to agency at the international level? Should an evaluation of agent effectiveness focus on environmental outcomes, behavioural changes, and/or effects on knowledge and discourse?

\subsection{The problem of adaptiveness}

Adaptiveness is the third analytical problem that we advance here. Adaptiveness is an umbrella term for a set of related concepts - vulnerability, resilience, adaptation, robustness, adaptive capacity or social learning - to describe changes made by social groups in response to, or in anticipation of, challenges created through environmental change (Adger 2006a; Folke 2006; Gallopin 2006; Smit and Wandel 2006). Within the framework of earth system governance, the term adaptiveness includes the governance of adaptation to socialecological change as well as the processes of change and adaptation within governance systems. We advance four main research questions under this theme.

1. First, what are the politics of adaptiveness? Adaptation can create winners and losers, by, for instance, shifting the distribution of benefits, of involuntary risks, or of power (Blaikie et al. 1994; Lebel et al. 2007, 2010a, b). The procedures and networks that foster adaptive capacity may reproduce and institutionalize prior injustice, for example, when actions in the logic of protecting national assets and interests make some disadvantaged groups or states more vulnerable than they were before (Paavola and Adger 2006). How institutions that are meant to help societies adapt to global environmental changes actually end up distributing the burdens and risks from earth system changes is an issue of social justice (Adger 2001; Thomas and Twyman 2005). We should therefore ask of adaptiveness: for whom and who benefits? Adaptive capacity is also often specific to the social-ecological system in question (Carpenter et al. 2001; Folke et al. 2003).

Societal responses that address some challenges are often contested both implicitly and overtly (Pritchard and Sanderson 2002; Lebel et al. 2006, 2010a, b). Most governance responses to single environmental challenges often have unintended repercussions in other fields and might be highly detrimental to other environmental, social or political goals (Shnaiberg et al. 2002). We should thus also ask of adaptiveness: To what and with which side effects? Who benefits from adaptation may not be identical to who has to adapt. If the state, as a set of institutions, is the most relevant level for tackling environmental changes, then we need to look at issues of state capacities and interdependencies because most governance systems, in particular in the developing world, are largely unprepared for the novel challenges related to the expected magnitude 
and diversity of increased environmental challenges (Biermann 2007). If adaptation is to be undertaken at a micro-level-in firms, civil society groups and neighbourhoods or in the behaviour of individuals - then possibilities for learning, innovation, selection and aggregation must be added to conventional concerns with fit and interplay (Young 2002). We should thus also ask: By what, under which conditions and at what administrative levels?

2. A second cluster of research questions addresses which governance processes foster adaptiveness. Earth system challenges are complex and the extent to which governance systems are adaptive and evolve in response to earth system challenges is not empirically clear in many problem domains. Creative responses to small changes, such as gradual sea-level rise or changing migration patterns of species, for example, by tinkering with institutions may appear to demonstrate adaptiveness. However, continuing to do so over decades and millennia may trap a society in a set of dependencies and vulnerabilities such that a different sort of challenge or surprise, even not a very big one, may have profound or catastrophic consequences (Erickson and Gowdy 2000; Diamond 2005; Gunderson and Holling 2002). Environmental changes unprecedented in scale or speed may bring about or demand changes to the criteria, scope and procedures by which power is allocated and decisions reached. Many studies, and most policy processes, concerned with adaptiveness are conservative in the sense that increasing resilience is seen as invariably positive and maintaining or returning to a recent system configuration as desirable (Lebel et al. 2006). Opportunities for institutional transformation in crises (Folke et al. 2005; Berkes 2007) are often overlooked. One reason is the politics associated with transformative change (Smith et al. 2005; Lebel et al. 2006). Another reason is the uncertainty and the novelty of future living conditions and potential new governance systems as well as the need to establish information and knowledge systems that support adaptive governance. In sum, governing transitions is a major challenge in itself (Olsson et al. 2004b; Smith et al. 2005; Olsson et al. 2006).

3. Third, parts of society do not just face one well-known environmental challenge at a time but may have to adapt to a range of challenges. Adequate governance mechanisms are thus necessary. This raises the question what attributes of governance systems enhance capacities to adapt? Do some forms of governance enhance capacities to adapt to environmental changes? While both adaptiveness and governance have associated with them large bodies of scholarly debate, there is relatively modest theorizing at their intersection in the context of earth system challenges (Folke et al. 2005; Adger 2006a; Lebel et al. 2006). Some suggest that participation is important to building and maintaining such a capacity because it creates trust. This might be, for example, through social networks that link actors together across organizational and other barriers (Olsson et al. 2004b; Folke et al. 2005; Lebel et al. 2010a, b). One important class of governance arrangements is adaptive co-management and its variants (Imperial 1999; Berkes et al. 2003; Berkes 2004, 2006; Tompkins and Adger 2004). These governance arrangements combine the ongoing generation of ecological knowledge on specific local and regional social-ecological systems with the flexible testing and iterative development of governance responses to these problems (Olsson et al. 2004a). One of the most common challenges associated with management of natural resources is to make participation of all relevant stakeholders meaningful (Agarwal 2001). Others have suggested that polycentric and multilayered institutions, because they improve the fit between knowledge, action, and social-ecological 
contexts in ways that allow societies to respond more adaptively at appropriate levels, should enhance capacities to adapt (Berkes 2002; Young 2002). Gupta et al. (2009), for example, have advanced an 'adaptive capacity wheel' with six dimensions and 22 criteria as a tool to assess the adaptive capacity of institutions. Such tools and methods are important and warrant further refinement.

4. The fourth and final research question is how, when and why adaptiveness influences earth system governance. It calls for deeper investigation of individual and collective behaviours that underlie adaptiveness, and, in particular, those related to the exercise, allocation and shaping of power. It requires research that aims to identify and understand causal chains (Elster 2007). This line of inquiry should continue and extend the emphasis on causality (of institutions) articulated in the research on the Institutional Dimensions of Global Environmental Change project (IDGEC1999; Young 2002) to the broader set of processes captured in notions of governance. Comparative and synthetic research of governance initiatives and routines could help to draw and test inferences about at least the gross prevalence of different mechanisms. A deeper understanding of mechanisms could help refine the now diverse notions and conceptualizations of adaptiveness, in particular with respect to their value for understanding and shaping earth system governance.

\subsection{The problem of accountability and legitimacy}

Increasingly important is also the question of the accountability and legitimacy of systems of governance, both in its own right with regard to the theory of democratic governance, and with a view of accountability and legitimacy as intervening variables that affect overall institutional effectiveness. In the twentieth century, legitimacy and accountability were problems of national governments. In the twenty-first century, with its emerging trends of governance beyond the state along with new needs of earth system governance, accountability and legitimacy appear in a different context (Biermann and Gupta, forthcoming). There are two broad types of research needs:

First, a theoretical one. In purely intergovernmental norm-setting processes, legitimacy derives indirectly through the accountability of governments to their voters. Likewise, international bureaucracies can derive legitimacy through their principals, the governments, which are accountable to their voters. However, such long lines of accountability have been questioned in recent years (Archibugi and Held 1995; Chan and Pattberg 2008; Commission on Global Governance 1995; Dingwerth 2005; Dryzek 1999; Held 1995). Many authors see a solution in the participation of private actors in global governance (Held 1999, 108). However, the accountability and legitimacy of private actors themselves is problematic (Biermann 2008, 294-296; Voss et al. 2006; Dilling et al. 2008; Gupta 2004; Dombrowski 2010). In the domestic context, private organizations may derive legitimacy through their members or donors, or from the environmental good they seek to protect. Yet in the international context, with its high disparities in wealth and power, accountability and legitimacy of private actors are more complicated. Most philanthropic organizations are headquartered in industrialized countries, and most funds donated to their cause stem from the North, both public and private. Disparities in representation exist also within countries. Given the financial requirements of participation, more rights and responsibilities for non-state actors could also privilege representatives of industry and business at the cost of other groups. 
This leads to a second, practical challenge: Because of these disparities, researchers need to design and practitioners to develop, institutions that guarantee participation of civil society through mechanisms that grant a balance of opinions and perspectives. Some authors, for example, propose strengthening private participation in a balanced way through quasi-corporatist institutionalization (Spiro 1994). Concerning more far-reaching proposals, the Commission on Global Governance (1995) for instance has proposed an international Forum of Civil Society within the United Nations, which would comprise of 300-600 "organs of global civil society" to be self-selected from civil society. Further research on both the theoretical foundations and the practical implications of different mechanisms for addressing problems of accountability and legitimacy in earth system governance is necessary.

The problem of accountability and legitimacy comes down to four specific research questions.

1. First, what are the sources of accountability and legitimacy in earth system governance? While the accountability and legitimacy of state actors remains of vital importance, there is a special need to study the accountability and legitimacy of new and emerging systems of governance that function without state actors, or in which state actors play only a marginal role (Kingsbury 2007). Both legitimacy and authority are difficult to define, and one exclusive definition might even be undesirable. Core elements of the concept of legitimacy are the acceptance and justification of authority. Acceptance relates to the way in which rules or institutions are accepted by a community as being authoritative. Justification relates to the reasons that justify the authority of certain rules or institutions (Bernstein 2005). Dingwerth (2007), for example, has distinguished three dimensions of democratic legitimacy beyond the state, namely participation and inclusiveness (to what extent have those who are subject to a decision been included in decision-making?), democratic control (that those who are governed can control those who govern them) and discursive quality. Overall, the accountability and legitimacy in earth system governance is still a major research frontier (Biermann and Gupta, forthcoming).

2. Second, what is the effect of different forms and degrees of accountability and legitimacy for the performance of governance systems? Accountability and legitimacy are important factors that influence the eventual performance of governance mechanisms. In general, institutions and governance can be expected to be more effective when their rules and representatives are perceived as accountable and legitimate. However, institutions and governance mechanisms-in particular in the realm of private and public-private cooperation-have established different types of accountability systems and different forms of legitimacy. It is important to understand how these relate to different degrees and types of performance of governance. Equally important is to understand potential trade-offs between requirements of (environmental) effectiveness and high standards of accountability and legitimacy.

3. Third, transparency has been emphasized as one mechanism to secure accountability and legitimacy of earth system governance. Yet the exact role and relevance of transparency is still insufficiently understood and requires further research on the question of how mechanisms of transparency can ensure accountable and legitimate earth system governance. Does it matter, for example, whether transparency is voluntary or mandatory; whether it hinges on information disclosure by states, private actors or from international organizations; or what kind of information is disclosed? Analysing the promise and the perils of what could be termed a 'transparency turn' in 
global governance can thus contribute to both the theoretical and practical dimensions of the quest for a more democratic earth system governance (Gupta 2008a; Mason 2008).

4. Fourth, what institutional designs can produce the accountability and legitimacy of earth system governance in a way that guarantees balances of interests and perspectives? Earth system governance must eventually involve actors at all levels of decisionmaking, and in all countries. Thus, systems of earth system governance must be legitimate for a large variety of actors, from the local level to the global level. Globally, legitimacy is particularly a problem with a view to the North-South divide (Gupta 2001, 2007): Both North and South, rich and poor, must accept the rules and regulations of the current and future systems of earth system governance as legitimate, and see their representatives as accountable. However, what kind of systems can generate this type of balance of interests and perspectives that ensures a high degree of global, comprehensive legitimacy (Biermann and Gupta, forthcoming)?

\subsection{The problem of allocation and access}

Who gets what, when, where and how is a key question of politics. The pursuit of fair allocation and access, and the un-doing of perceived injustices, is a never-ending but meaningful goal. The impacts of global change pose additional challenges, for instance in the way environmental risks are distributed across peoples and places (Banuri et al. 1996) or in the way that responses are favoured and supported by stronger societies (Thomas and Twyman 2005). The research theme of allocation is difficult also because what constitutes fair allocation and access is tangled up in details of both objectives and means to achieve them. These vary widely and reflect beliefs about how the world is, or should be; they are also path-determined. There is some limited research on international environmental regimes emphasizing justice at the level of nation states. This needs to be strengthened in itself, yet also be complemented by research into allocation and access questions within states. Such research will have to tackle moral and ethical issues; it is here where questions of allocation can easily become trapped into forgetting the shaping contexts that empower and disenfranchize from the start (Rawls 1997; Dryzek 2000).

We propose four sets of questions to guide research on the analytical problem of allocation and access.

1. First, how can we reach interdisciplinary conceptualizations and definitions of allocation and access? Given the breadth of debates on allocation, it seems important to improve interdisciplinary understandings (Gupta and Lebel 2010). So far allocation and access are defined differently in different disciplines: Lawyers speak of equity, economists of distribution, resource analysts of access, political scientists of fairness, geographers of socio-spatial distributions and environmental justice, and sociologists of social justice. Related to this is the question of how one can operationalize the concept of allocation and access for the governance of large-scale environmental changes with uncertain, heterogeneous and partly delayed social implications. How can one measure success in achieving fair allocation and access?

2. Second, what is the relevance of questions of allocation and access in earth system governance? We need a better understanding of the influence of allocation and access on earth system governance, as well as of how earth system governance and processes of earth system transformation affect allocation and access. For example, to what extent is poor access and unequal allocation at local or global levels a cause of 
increased vulnerability to global environmental change, and to what extent is it a cause of global environmental change? Important here is also the analysis of differences. Which differences are most relevant to the increased and new vulnerabilities created by global environmental change? How can they be addressed? Who should be empowered and who held responsible for addressing them? What techniques allow us to understand and measure difference? How can vulnerable communities be empowered in different contexts to protect themselves?

3. Third, what (overarching) principles underlie allocation and access? It seems important to advance understanding to what extent principles of allocation and access are similar across issue areas, and to what extent successful principles can be adapted from one issue area to another. What contextual factors enhance the strengths and reduce the weaknesses of principles of allocation and access, and under what circumstances can instruments that provide for fair allocation and access be scaled up and down?

4. The fourth and final question is how to reconcile allocation and access with governance effectiveness. It is important to analyse the implications of current and alternative initiatives to improve allocation and access within earth system governance. How can these be redirected to the pursuit of fair allocation and access without reducing their effectiveness in addressing environmental consequences and drivers of global change?

\section{Crosscutting themes}

The five analytical problems are the basis of earth system governance research. They all share a number of crosscutting themes, that is, core concerns of the social sciences that are of fundamental relevance for the analysis of each analytical problem. Four crosscutting themes have been selected for closer examination within the Earth System Governance Project: these are power, knowledge, norms and scale.

\subsection{Power}

As ubiquitously as the term power is used, as difficult as it is to conceptualize it; yet despite its centrality, how power is conceived in studies of governance and institutions is often not discussed (Barnett and Duvall 2005; Lebel 2006a). What is the nature of power, for example, in multilevel and network arrangements of earth system governance? Where does it lie? What are its sources? How is it exercised? Drawing on Max Weber, power is conventionally defined as getting others to do one's bidding against their own interests and even resistance. But it can be exercised or expressed in many ways, and that is where complexity and nuances enter. There is power to and power over. Power is about the capacity to take away or to grant freedoms. This does not mean that actors have to meet physically. Power may involve manipulating circumstances for others (Lukes 1974). Drawing on Albert Hirschman (1945), asymmetrical interdependence is used sometimes to describe sources of power: if you are more dependent on someone than they are on you, you are less powerful. Perceptions about relative power, however, may be inaccurate. Moreover, much about power is about gaining the right to speak on behalf of others, which may require strategies of the powerful that underplay power. The higher and more subtle dimensions of power can lead to deceptively peaceful settings in which consent has been manufactured and dissent vaporized. 


\subsection{Knowledge}

Knowledge is relevant, first, in the form of scientific information that plays a major role in most processes of earth system governance. Research on earth system governance is thus inevitably also research on the role that science plays in these processes, and eventually must be reflexive, in allowing for improved understanding on the underlying theories, methods and assumptions (van Kerkhoff and Lebel 2006). The boundary between researchbased knowledge and decision-making is not hard and fixed, but rather semi-permeable, moveable and negotiated (Jasanoff 2003; Jasanoff and Wynne 1998). Earth system governance thus requires a reflexive and carefully designed approach to organize and utilize some boundary functions, like mediation or translation, for example through creating specific boundary organizations (Cash et al. 2003; Guston 2001; Lebel 2010a). Knowledge is pertinent also in the role of scientific assessments in earth system governance. Research suggests that assessments that are perceived by all key stakeholders to be legitimate, credible and salient, are those that have the most influence (Biermann 2002; Mitchell et al. 2006). Assessments that are overly driven by science easily become trapped by their framing of issues, for example, into what is easily measured. Tacit, practice-based, experiential and research-based knowledge may be complementary and usefully hybridized (Forsyth 1998, 2003), but they can also be pitted against each other and against other systems of belief. Knowledge and knowledge systems are often created and stimulated by those with resources. This may push science and scientific results in specific directions and marginalize other scientific research questions and methodologies, often affecting especially developing country concerns and interests. One can capture this in notions of the politics of science (Annan 2003; Gupta 1997; Gupta and van der Zaag 2009) or of governmentality, as science is used to discipline both humans and environments (Bäckstrand and Lövbrand 2006).

\subsection{Norms}

Third, in exploring each analytical problem of earth system governance, researchers will have to deal with the role of overarching norms, values and broader ideational structures, which have become the focus of much attention in research (see for example March and Olsen 1989, 1996, 1998; Barnett and Finnemore 2004). Also, in earth system governance, it will be important to increase understanding not only of singular institutions, but of "collections of norms and the mix of rules and practices that structure ... institutions" (Finnemore and Sikkink 1998, 891).

\subsection{Scale}

Fourth, it will be important to identify whether certain findings or hypotheses apply on all scales, or are valid merely for one scale, for example only for the international or only for the local level. Likewise, researchers will have to analyse to what extent scale influences their finding. Scale is defined as the spatial, temporal, quantitative or analytical dimensions used to measure or rank any phenomenon. Level is the unit of analysis located at different positions on a scale (Gibson et al. 2000). Scale is not an easy concept as disciplines deal with it differently. However, the concept also has a strong unifying effect, since a focus on scale and ways of scaling produces cross-disciplinary fertilization and richer analysis (Cumming et al. 2006). Many issues related to earth system transformation are perceived as multilevel (Cash et al. 2006), and actors contest scales and levels by shifting issues to 
those at which they are most influential or powerful (Lebel 2006b; Lebel et al. 2005; Meadowcroft 2002; Gupta 2008b). ${ }^{3}$

\section{Interlinkages}

The five analytical problems, and the four crosscutting themes they share, depend on each other with a multitude of possible interactions.

For instance, the problems of architecture and agency are linked through questions of how institutions and other governance mechanisms emerge, change or, conversely, are able to remain static for long periods-hence creating or restraining agency (see Schroeder 2010). Also, the links between the problems of architecture and allocation are a recurrent theme in earth system governance. Questions about equity, justice and fairness remain at the core of much of the political debate over the design and implementation of large-scale environmental and development institutions. As another example, the problems of architecture and accountability are linked because the multilevel characteristics of earth system governance extend beyond the central government but also require local responses. Similarly, the analytical problems of agency and architecture in earth system governance are related as part of the broader agent-structure debate in the social sciences. Agents shape, and are shaped by, the broader architecture of earth system governance.

As another example, the analytical problem of allocation and access is closely related to the other four problems: Questions of allocation and access can only be resolved if integrated into the larger architecture of earth system governance and can shape or be shaped by this architecture (Kanie et al. 2010). Allocation and access are related to agency, for instance since disadvantaged communities are often not empowered to participate in decision-making as fully effective agents. Allocation and access is also linked to accountability and legitimacy, since systems of accountability often do not take into account the needs of marginalized communities (see Dombrowski 2010).

Likewise, the problem of adaptiveness has important links to those of allocation (risk management) and agency (by whom?). The significance of the politics of adaptiveness is largely in how it allocates risks and benefits from earth system transformation and societal responses to it. The allocation of burdens to act upon also raises questions about capabilities, motivations and influence. It also requires social learning processes, and the inclusion of various forms of knowledge that are important for building adaptiveness in several ways and at different scales (see Lebel et al. 2010a). Finally, at the intersection of the problems of allocation and accountability lie issues critical to performance. For instance, if outcomes in terms of social-ecological sustainability and human wellbeing are not achieved, authorities need to be held accountable.

\section{Earth system governance as a challenge for research and policy}

The Earth System Governance Project, while primarily a scientific initiative, is also designed to assist policy. Significant policy-relevant contributions from research are expected in all five analytical problem areas. For example, the problem of the architecture of earth system governance is a key concern of current negotiations and political processes

\footnotetext{
3 To further focus initial efforts, four flagship activities, or case study areas, have been identified (see for more detail Biermann et al. 2009a, 87-109): the global water, food, climate and economic systems.
} 
that are often faced with 'treaty congestion' and complex interlinkages between different institutions, for instance between multilateral environmental agreements and the World Trade Organization. 'Fragmented' governance architectures are also an increasing problem for decision-makers, particularly in climate policy. A related concern is the reform of the United Nations, for example with a view to the debate on a United Nations Environment Organization (Biermann et al. 2009b). At national and local levels, architecture is a key concern for decision-makers dealing with policy integration, the comparative effectiveness of policy instruments, and the integration of decision-making from international, national and local levels. Research on agency within the project will generate novel ideas on the integration of civil society actors in earth system governance, and on the advantages and disadvantages of private and public-private governance arrangements. Research on governance of adaptation and the adaptiveness of governance arrangements will inform policymakers who have to deal with adapting politics and policies to a changing world. The accountability and legitimacy of decision-making, from local to global levels, is equally a key problem for public policy. Finally, new research on allocation and access will help to improve governance outcomes and advance philosophical and ethical discourses on an equitable approach to earth system governance.

Earth system governance is one of the most difficult yet at the same time one of the most exciting and urgent research topics for the social sciences. The five analytical problems and four crosscutting research themes (Fig. 1) of the Earth System Governance Project's science programme provide a starting point for advancing and integrating many different strands and disciplines of research. Undoubtedly, other problems and themes will emerge as the programme matures. Yet the framework advanced here provides, we argue, a first overall conceptualization of this vital emerging research field in the social sciences that forms a valuable foundation for further research efforts.

Open Access This article is distributed under the terms of the Creative Commons Attribution Noncommercial License which permits any noncommercial use, distribution, and reproduction in any medium, provided the original author(s) and source are credited.

\section{References}

Adger, N. W. (2001). Scales of governance and environmental justice for adaptation and mitigation of climate change. Journal of International Development, 13, 921-931.

Adger, N. W. (2006a). Vulnerability. Global Environmental Change, 16, 268-281.

Adger, N. W. (2006b). The political economy of cross-scale networks in resource co-management. Ecology and Society, 10(2), article 9. [online: http://www.ecologyandsociety.org/vol10/iss2/art9].

Adger, N. W., \& Jordan, A. J. (Eds.). (2008). Governing sustainability. Cambridge, UK: Cambridge University Press.

Agarwal, B. (2001). Participatory exclusions, community forestry, and gender: An analysis for South Asia and a conceptual framework. World Development, 29, 1623-1648.

Andonova, L. B., \& Levy, M. A. (2003). Franchising global governance. In O. S. Stokke \& O. B. Thommessen (Eds.), Yearbook of international cooperation on environment and development (pp. 19-32). London: Earthscan.

Andresen, S., Skodvin, T., Underdal, A., \& Wettestad, J. (Eds.). (2000). Science and politics in international environmental regimes: Between integrity and involvement. Manchester: Manchester University Press.

Annan, K. (2003). A challenge to the world's scientists. Science, 299, 1485.

Archibugi, D., \& Held, D. (Eds.). (1995). Cosmopolitan democracy: An agenda for a new world order. Oxford: Polity Press.

Bäckstrand, K., \& Lövbrand, E. (2006). Planting trees to mitigate climate change: Contested discourses of ecological modernization, green governmentality and civic environmentalism. Global Environmental Politics, 6, 50-75. 
Banuri, T., Goran-Maler, K., Grubb, M., Jacobson, H. K., \& Yamin, F. (1996). Equity and social considerations. In J. Bruce, L. Hoesung, \& E. Haites (Eds.), Climate change (1995): Economic and social dimensions of climate change (pp. 79-124). Cambridge, UK: Cambridge University Press.

Barnett, M. N., \& Duvall, R. (2005). Power in international politics. International Organization, 59, 39-75.

Barnett, M. N., \& Finnemore, M. (2004). Rules for the world: International organizations in global politics. Ithaca: Cornell University Press.

Berkes, F. (2002). Cross-scale institutional linkages for commons management: Perspectives from the bottom up. In E. Ostrom, T. Dietz, N. Dolsak, P. C. Stern, S. Stonich, \& E. U. Weber (Eds.), The drama of the commons (pp. 293-321). Washington DC: National Academy Press.

Berkes, F. (2004). Rethinking community-based conservation. Conservation Biology, 18, 621-630.

Berkes, F. (2006). From community-based resource management to complex systems. Ecology and Society, $11(1), 45$.

Berkes, F. (2007). Understanding uncertainty and reducing vulnerability: Lessons from resilience thinking. Natural Hazards, 41, 283-295.

Berkes, F., Colding, J., \& Folke, C. (Eds.). (2003). Navigating social-ecological systems: Building resilience for complexity and change. Cambridge, UK: Cambridge University Press.

Bernstein, S. (2001). The compromise of liberal environmentalism. New York: Colombia University Press.

Bernstein, S. (2005). Legitimacy in global environmental governance. Journal of International Law and International Relations, 1(1-2), 139-166.

Betsill, M. M. (2006). Transnational actors in international environmental politics. In M. M. Betsill, K. Hochstetler, \& D. Stevis (Eds.), International Environmental Politics (pp. 172-202). Basingstoke: Palgrave Macmillan.

Betsill, M. M., \& Bulkeley, H. (2004). Transnational networks and global environmental governance: The cities for climate protection program. International Studies Quarterly, 48, 471-493.

Betsill, M. M., \& Bulkeley, H. (2006). Cities and the multilevel governance of global climate change. Global Governance, 12(2), 141-159.

Betsill, M. M., \& Corell, E. (Eds.). (2008). NGO diplomacy: The influence of nongovernmental organizations in international environmental negotiations. Cambridge, MA: MIT Press.

Biermann, F. (2002). Institutions for scientific advice: Global environmental assessments and their influence in developing countries. Global Governance, 8(2), 195-219.

Biermann, F. (2007). 'Earth system governance' as a crosscutting theme of global change research. Global Environmental Change. Human and Policy Dimensions, 17, 326-337.

Biermann, F. (2008). Earth system governance. A research agenda. In O. R. Young, L. A. King, \& H. Schroeder (Eds.), Institutions and environmental change: Principal findings, applications, and research frontiers (pp. 277-302). Cambridge, MA: MIT Press.

Biermann, F., Betsill, M. M., Gupta, J., Kanie, N., Lebel, L., Liverman, D., Schroeder, H. \& Siebenhüner, B. with contributions from K. Conca, L. da Costa Ferreira, B. Desai, S. Tay \& R. Zondervan (2009a). Earth system governance: People, places and the planet. Science and Implementation Plan of the Earth System Governance Project. Earth System Governance Report 1, IHDP Report 20. (Bonn, IHDP: The Earth System Governance Project).

Biermann, F., Chan, M.-S., Mert, A., \& Pattberg, P. (2007). Multi-stakeholder partnerships for sustainable development. Does the promise hold? In P. Glasbergen, F. Biermann, \& A. P. J. Mol (Eds.), Partnerships, governance, and sustainable development: Reflections on theory and practice (pp. 239-260). Cheltenham: Edward Elgar.

Biermann, F., Davis, O., \& van der Grijp, N. (2009b). Environmental policy integration and the architecture of global environmental governance. International Environmental Agreements: Politics, Law and Economics, 9, 351-369.

Biermann, F. \& Gupta, A. (Eds.) (forthcoming). Accountability and legitimacy in earth system governance. Ecological Economics.

Biermann, F., \& Pattberg, P. (2008). Global environmental governance: Taking stock, moving forward. Annual Review of Environment and Resources, 33, 277-294.

Biermann, F., Pattberg, P., van Asselt, H., \& Zelli, F. (2009c). The fragmentation of global governance architectures: a framework for analysis. Global Environmental Politics, 9(4), 14-40.

Biermann, F., \& Siebenhüner, B. (2009). Managers of global change: The influence of international environmental bureaucracies. Cambridge, MA: MIT Press.

Blaikie, P., Cannon, T., Davis, I., \& Wisner, B. (1994). At risk: Natural hazards, people's vulnerability and disaster. London: Routledge.

Breitmeier, H., Young, O. R., \& Zürn, M. (2006). Analyzing international environmental regimes: From case study to database. Cambridge, MA: The MIT Press. 
Brunnée, J. (2002). Coping with consent: Law-making under multilateral environmental agreements. Leiden Journal of International Law, 15, 1.

Bulkeley, H., \& Betsill, M. M. (2003). Cities and climate change: Urban sustainability and global environmental governance. London and New York: Routledge.

Carpenter, S., Walker, B., Anderies, J. M., \& Abel, N. (2001). From metaphor to measurement: resilience of what to what? Ecosystems, 4, 765-781.

Cash, D. W., Adger, W. N., Berkes, F., Garden, P., Lebel, L., Olsson, P., Pritchard, L. \& Young, O. R. (2006). Scale and cross-scale dynamics: governance and information in a multilevel world. Ecology and Society, 11 (2): Article 8 [online: http://www.ecologyandsociety.org/vol11/iss2/art8/].

Cash, D., Clark, W. C., Alcock, F., Dickson, N. M., Eckley, N., Guston, D. H., et al. (2003). Knowledge systems for sustainable development. PNAS, 100(14), 8086-8091.

Cashore, B. (2002). Legitimacy and the privatization of environmental governance: How non-state marketdriven (NSMD) governance systems gain rule-making authority. Governance, 15(4), 503-529.

Chambers, W. B. (Ed.). (2001). Inter-Linkages: The Kyoto Protocol and the international trade and investment regimes. Tokyo: United Nations University Press.

Chan, M.-S., \& Pattberg, P. (2008). Private rule-making and the politics of accountability: analyzing global forest governance. Global Environmental Politics, 8(3), 103-121.

Commission on Global Governance (1995). Our global neighbourhood. The report of the Commission on Global Governance. (Oxford: Oxford University Press).

Cumming, G. S., Cumming, D. H. M. \& Redman, C. L. (2006). Scale mismatches in social ecological systems: Causes, consequences and solutions. Ecology and Society, 11(1), article 14 [online: http://www.ecologyandsociety.org/col11/iss1/art14/].

Diamond, J. (2005). Collapse: How societies choose to fail or succeed. New York: Viking Press.

Dilling, O., Herberg, M., \& Winter, G. (2008). Responsible business: Self-governance and law in transnational economic transactions. Oxford: Hart.

Dingwerth, K. (2005). The democratic legitimacy of public-private rule-making. What can we learn from the World Commission on Dams? Global Governance, 11(1), 65-83.

Dingwerth, K. (2007). The new transnationalism. Transnational governance and democratic legitimacy. Basingstoke: Palgrave Macmillan.

Dombrowski, K. (2010) Filling the gap? An analysis of NGO responses to participation and representation deficits in global climate governance. International Environmental Agreements: Politics, Law and Economics, 10(4).

Dryzek, J. S. (1999). Transnational democracy. The Journal of Political Philosophy, 7(1), 30-51.

Dryzek, J. S. (2000). Deliberative democracy and beyond: Liberals, critics, contestations. Oxford: Oxford University Press.

Elster, J. (2007). Explaining social behavior: More nuts and bolts for the social sciences. New York: Cambridge University Press.

Erickson, J., \& Gowdy, J. (2000). Resource use, institutions and sustainability: A tale of two pacific island cultures. Land Economics, 76, 345-354.

ESSP_Earth System Science Partnership. (2001). The Amsterdam declaration on global change. Retrieved 10 September 2009 from http://www.essp.org/index.php?id=41.

Finnemore, M., \& Sikkink, K. (1998). International norm dynamics and political change. International Organization, 52(4), 887-917.

Folke, C. (2006). Resilience: the emergence of a perspective for social-ecological systems analyses. Global Environmental Change, 16, 253-267.

Folke, C., Colding, J., \& Berkes, F. (2003). Synthesis: Building resilience and adaptive capacity in socialecological systems. In F. Berkes, J. Colding, \& C. Folke (Eds.), Navigating social-ecological systems: Building resilience for complexity and change (pp. 352-387). Cambridge, UK: Cambridge University Press.

Folke, C., Hahn, T., Olsson, P., \& Norberg, J. (2005). Adaptive governance of social-ecological systems. Annual Review Environment Resources, 30, 441-473.

Forsyth, T. (1998). Mountain myths revisited: Integrating natural and social environmental science. Mountain Research and Development, 18(2), 126-139.

Forsyth, T. (2003). Critical political ecology: The politics of environmental science. London: Routledge.

Gallopin, G. (2006). Linkages between vulnerability, resilience and adaptive capacity. Global Environmental Change, 16, 293-303.

Gehring, T., \& Oberthür, S. (2008). Interplay: Exploring institutional interaction. In O. R. Young, L. A. King, \& H. Schroeder (Eds.), Institutions and environmental change: Principal findings, applications and research frontiers (pp. 187-224). Cambridge, MA: MIT Press. 
Gibson, C. C., Ostrom, E., \& Ahn, T.-K. (2000). The concept of scale and the human dimensions of global change: A survey. Ecological Economics, 32, 217-239.

Glasbergen, P., Biermann, F., \& Mol, A. P. J. (Eds.). (2007). Partnerships, governance, and sustainable development: Reflections on theory and practice. Cheltenham: Edward Elgar.

Gunderson, L. H., \& Holling, C. S. (Eds.). (2002). Panarchy: Understanding transformations in human and natural systems. Washington, DC: Island Press.

Gupta, J. (1997). The climate change convention and developing countries: From conflict to consensus? Dordrecht: Kluwer Academic Publishers.

Gupta, J. (2001). Legitimacy in the real world: A case study of the developing countries, non-governmental organizations and climate change. In J.-M. Coicaud \& V. Heiskanen (Eds.), The legitimacy of international organizations (pp. 482-518). Tokyo: United Nations University Press.

Gupta, J. (2004). Non-state actors: Undermining or increasing the legitimacy and transparency of international environmental law. (In I. F. Dekker \& W. Werner (Eds.). Governance and international legal theory (pp. 297-320). Nova Et Vetera Iuris Gentium.).

Gupta, J. (2007). International law and climate change: The challenges facing developing countries. Yearbook of International Environmental Law (Oxford University Press), 16, 114-153.

Gupta, A. (2008a). Transparency under scrutiny: Information disclosure in global environmental governance. Global Environmental Politics, 8(2), 1-7.

Gupta, J. (2008b). Global change: Analysing scale and scaling in environmental governance. In O. R. Young, H. Schroeder, \& L. A. King (Eds.), Institutions and environmental change: Principal findings, applications, and research frontiers (pp. 225-258). Cambridge, MA: MIT Press.

Gupta, J. \& Lebel, L. (2010). Access and allocation in earth system governance: Water and climate change compared. International Environmental Agreements: Politics, Law and Economics, 10(4).

Gupta, J., Termeer, K., Klostermann, J., Meijerink, S., van den Brink, M., Jong, P. \& Nooteboom, S. (2009). Institutions for climate change: A method to assess the inherent characteristics of institutions to enable the adaptive capacity of society. Available on Glogov website http://glogov.org/?pageid=4.

Gupta, J., \& van der Zaag, P. (2009). The politics of water science: Unresolved water problems and biased research agendas. Global Environmental Politics, 9(2), 14-23.

Guston, D. H. (2001). Boundary organizations in environmental policy and science: an introduction. Science. Technology and Human Values, 26(4), 399-408.

Haas, P. M. (1993). Introduction: Epistemic communities and international policy coordination. International Organization, 47, 1-35.

Haufler, V. (2000). Private sector international regimes. In R. A. Higgott, G. R. D. Underhill, \& A. Bieler (Eds.), Non-state actors and authority in the global system (pp. 121-137). London, New York: Routledge.

Held, D. (1995). Democracy and the global order: From the modern state to cosmopolitan governance. Cambridge: Polity Press.

Held, D. (1999). The transformation of political community. In I. Shapiro \& C. Hacker-Cordon (Eds.), Democracy's edges (pp. 84-111). Cambridge, UK: Cambridge University Press.

Hirschman, A. O. (1945/1980). National power and the structure of foreign trade. (Berkeley: University of California Press).

Hooghe, L., \& Marks, G. (2003). Unravelling the central state, but how? Types of multi-level governance. American Political Science Review, 97(2), 233-243.

Imperial, M. T. (1999). Institutional analysis and ecosystem-based management: The institutional analysis and development framework. Environmental Management, 24, 449-465.

Institutional Dimensions of Global Environmental Change Project. (1999). Science Plan, by O. R. Young with contributions from A. Agrawal, L. A. King, P. H. Sand, A. Underdal and M. Wasson (= IHDP Report No. 9) (Bonn: IHDP).

Jasanoff, S. (2003). Technologies of humility: Citizen participation in governing science. Minerva, 41(3), $223-244$.

Jasanoff, S., \& Wynne, B. (1998). Science and decision-making. In S. Rayner \& E. L. Malone (Eds.), Human choice and climate change: The societal framework (pp. 1-87). Columbus, Ohio: Batelle Press.

Jordan, A. J. (2008). The governance of sustainable development: Taking stock and looking forwards. Environmental and Planning C, 26, 17-33.

Kanie, N., \& Haas, P. M. (Eds.). (2004). Emerging forces in environmental governance. Tokyo: United Nations University Press.

Kanie, N., Hiromi, N., Yasuaki, H. \& Yasuko, K. (2010) Allocation and architecture in climate governance beyond Kyoto: Lessons from interdisciplinary research on target setting. International Environmental Agreements: Politics, Law and Economics, 10(4). 
Kingsbury, B. (2007). Global environmental governance as administration: Implications for international law. In D. Bodansky, J. Brunnée, \& E. Hey (Eds.), Oxford Handbook of International Environmental Law (pp. 63-84). New York: Oxford University Press.

Kingsbury, B., Krisch, N., \& Stewart, R. B. (2005). The emergence of global administrative law. Law and Contemporary Problems, 68, 15-61.

Krisch, N. (2006). The pluralism of global administrative law. European Journal of International Law, 17(1), 247-278.

Lebel, L. (2006a). Reflections on power. USER briefing BN-2006-10. (Chiang Mai: Unit for Social and Environmental Research) [online: http://www.sea-user.org/uweb.php?pg=170].

Lebel, L. (2006b). The politics of scale in environmental assessment. In W. V. Reid, F. Berkes, T. J. Wilbanks, \& D. Capistrano (Eds.), Bridging scales and knowledge systems: Concepts and applications in ecosystem assessment (pp. 37-57). New York: Island Press.

Lebel, L., Anderies, J. M., Campbell, B., Folke, C., Hatfield-Dodds, S., Hughes, T., et al. (2006). Governance and the capacity to manage resilience in regional social-ecological systems. Ecology and Society, 11(1), 11-19.

Lebel, Dore, L. J., Daniel, R., \& Koma, Y. S. (Eds.). (2007). Democratizing water governance in the Mekong region. Chiang Mai: Mekong Press.

Lebel, L., Garden, P. \& Imamura, M. (2005). Politics of scale, position and place in the governance of water resources in the Mekong region. Ecology and Society, 10(2), article18. [online: http://www.ecologyandsociety.org/vol10/iss2/art18/].

Lebel, L., Grothmann, T. \& Siebenhüner, B. (2010a). The role of social learning in adaptiveness: insights from water management. International Environmental Agreements: Politics, Law and Economics, 10(4).

Lebel, L., Xu, J., Bastakoti, R. C. \& Lamba, A. (2010b). Pursuits of adaptiveness in the shared rivers of Monsoon Asia. International Environmental Agreements: Politics, Law and Economics, 10(4).

Leemans, R., Asrar, G., Busalacchi, A., Canadell, J., Ingram, J., Larigauderie, A., et al. (2009). Developing a common strategy for integrative global environmental change research and outreach: the Earth System Science Partnership (ESSP). Current Opinion in Environmental Sustainability, 1(1), 4-13.

Levy, D. L., \& Newell, P. J. (Eds.). (2004). The business of global environmental governance. Cambridge, MA: MIT Press.

Lukes, S. (1974). Power: A radical view. London: Macmillan.

March, J. G., \& Olsen, J. P. (1989). Rediscovering institutions: The organizational basis of politics. New York: Free Press.

March, J. G., \& Olsen, J. P. (1996). Institutional perspectives on political institutions. Governance. An International Journal of Policy and Administration, 9(3), 247-264.

March, J. G., \& Olsen, J. P. (1998). The institutional dynamics of international political orders. International Organization, 52(4), 943-969.

Mason, M. R. (2008). The governance of transnational environmental harm: Addressing new modes of accountability/responsibility. Global Environmental Politics, 8(3), 8-24.

Meadowcroft, J. (2002). Politics and scale: Some implications for environmental governance. Landscape and Urban Planning, 61, 169-179.

Mitchell, R. B. (2008). Evaluating the performance of environmental institutions: What to evaluate and how to evaluate it? In O. R. Young, L. A. King, \& H. Schroeder (Eds.), Institutions and environmental change: Principal findings, applications, and research frontiers (pp. 79-114). Cambridge, MA: MIT Press.

Mitchell, R. B., Clark, W. C., Cash, D., \& Dickson, N. M. (Eds.). (2006). Global environmental assessments: Information and influence. Cambridge, MA: MIT Press.

Oberthür, S., \& Gehring, T. (Eds.). (2006). Institutional interaction in global environmental governance. Synergy and conflict among international and EU policies. Cambridge, MA: MIT Press.

Olsson, P., Folke, C., \& Berkes, F. (2004a). Adaptive comanagement for building resilience in socialecological systems. Environmental Management, 34, 75-90.

Olsson, P., Folke, C. \& Hahn, T. (2004b). Social-ecological transformation for ecosystem management: The development of adaptive co-management of a wetland landscape in southern Sweden. Ecology and Society, 9, article 2. [online: http://www.ecologyandsociety.org/vol9/iss4/art2].

Olsson, P., Gunderson, L. H., Carpenter, S. R., Ryan, P., Lebel, L., Folke, C., et al. (2006). Shooting the rapids: Navigating transitions to adaptive governance of social-ecological systems. Ecology and Society, 11: article 18. [online: http://www.ecologyandsociety.org/vol11/iss11/art18/].

Paavola, J., \& Adger, W. N. (2006). Fair adaptation to climate change. Ecological Economics, 56(3), 594-609. 
Pattberg, P. (2005). The institutionalization of private governance: How business and non-profits agree on transnational rules. Governance: An International Journal of Policy, Administration, and Institutions, 18(4), 589-610.

Pattberg, P. (2006). The influence of global business regulation: Beyond good corporate conduct. Business and Society Review, 111(3), 241-268.

Pattberg, P., \& Stripple, J. (2008). Beyond the public and private divide: remapping transnational climate governance in the 21st century. International Environmental Agreements, 8(4), 367-388.

Pritchard, L. J., \& Sanderson, S. E. (2002). The dynamics of political discourse in seeking sustainability. In L. H. Gunderson \& C. S. Holling (Eds.), Panarchy: Understanding transformations in human and natural systems (pp. 147-169). Washington: Island Press.

Rabe, B. G. (2006). Power to the states: The promise and pitfalls of decentralization. In N. J. Vig \& M. E. Kraft (Eds.), Environmental policy: New directions for the twenty-first century (pp. 34-56). Washington, DC: CQ Press.

Rawls, J. (1997). The idea of public reason revisited. The University of Chicago Law Review, 64, 765-807.

Risse, T., Ropp, S. C., \& Sikkink, K. (Eds.). (1999). The power of human rights: International norms, and domestic change. Cambridge, UK: Cambridge University Press.

Rockström, J., Steffen, W., Noone, K., Persson, A., Stuart Chapin, F., Lambin, E. F., et al. (2009). A safe operating space for humanity. Nature, 461, 472-475 (24 Sept 2009).

Rosenau, J. N. (1995). Governance in the twenty-first century. Global Governance, 1(1), 13-43.

Rosendal, G. K. (2001a). Impacts of overlapping international regimes: The case of biodiversity. Global Governance, 7(1), 95-117.

Rosendal, G. K. (2001b). Overlapping international regimes. International Environmental Agreements: Politics, Law and Economics, 1(4), 447-468.

Rowlands, I. H. (2001). Transnational corporations and global environmental politics. In D. Josselin \& W. Wallace (Eds.), Non-state actors in world politics (pp. 133-149). London: Palgrave.

Scheberle, D. (2004). Federalism and environmental policy: Trust and the politics of implementation, revised edition. Washington, DC: Georgetown University Press.

Schellnhuber, H.-J. (1999). Earth system analysis and the Second Copernican Revolution. Nature, 402 (= Millennium Supplement, 2 December 1999) C19-C23.

Schroeder, H. (2008). Analyzing biosafety and trade through the lens of institutional interplay. In O. R. Young, W. B. Chambers, J. A. Kim, \& C. Ten Have (Eds.), Institutional interplay: The case of biosafety. Tokyo: United Nations University Press.

Schroeder, H. (2010). Agency in international climate negotiations: The case of indigenous peoples and avoided deforestation. International Environmental Agreements: Politics, Law and Economics, 10(4).

Selin, H., \& VanDeveer, S. (2005). Canadian-U.S. environmental cooperation: Climate change networks and regional action. American Review of Canadian Studies, 35(2), 353-378.

Shnaiberg, J., Riera, J., Turner, M. G., \& Voss, P. R. (2002). Explaining human settlement patterns in a recreational lake district: Vilas County, Wisconsin, USA. Environmental Management, 30, 24-34.

Smit, B., \& Wandel, J. (2006). Adaptation, adaptive capacity, and vulnerability. Global Environmental Change, 16, 282-292.

Smith, A., Stirling, A., \& Berkhout, F. (2005). The governance of sustainable socio-technical transitions. Research Policy, 34, 1491-1510.

Sornarajah, M. (2006). A law for need or a law for freed. International Environmental Agreements: Politics. Law and Economics, 6(4), 329-357.

Sourgens, F. G. (2007). ICSID arbitration and the importance of public accountability of a private judicature: A Roman law perspective. International Community Law Review, 9, 59-102.

Spiro, P. J. (1994). New global communities: Nongovernmental organizations in international decisionmaking institutions. The Washington Quarterly, 18(1), 45-56.

Steffen, W., Sanderson, A., Tyson, P. D., Jäger, J., Matson, P. M., Moore, B., III et al. (2004). Global change and the earth system: A planet under pressure. New York: Springer.

Stokke, O. S. (2000). Managing straddling stocks: The interplay of global and regional regimes. Ocean and Coastal Management, 43(2-3), 205-234.

Thomas, D. S. G., \& Twyman, C. (2005). Equity and justice in climate change adaptation amongst naturalresource-dependent societies. Global Environmental Change, 15, 115-124.

Tienhaara, K. (2006). What you don't know can hurt you: Investor state disputes and the environment. Global Environmental Politics, 6(4), 73-100.

Tompkins, E. L. \& Adger, N. W. (2004). Does adaptive management of natural resources enhance resilience to climate change? Ecology and Society, 9, article 10. [online: http://www.ecologyandsociety.org/ vol19/iss12/art10/]. 
Underdal, A. (2008). Determining the causal significance of institutions: Accomplishments and challenges. In O. R. Young, L. A. King, \& H. Schroeder (Eds.), Institutions and environmental change: Principal findings, applications, and research frontiers (pp. 49-78). Cambridge, MA: MIT Press.

Underdal, A., \& Young, O. R. (Eds.). (2004). Regime consequences. Dordrecht: Kluwer.

van Kerkhoff, L., \& Lebel, L. (2006). Linking knowledge and action for sustainable development. Annual Review of Environment and Resources, 31, 445-477.

van Kersbergen, K., \& van Waarden, F. (2004). 'Governance' as a bridge between disciplines: Crossdisciplinary inspiration regarding shifts in governance and problems of governability, accountability and legitimacy. European Journal of Political Research, 43, 143-171.

VanNijnatten, D. L., \& Boardman, R. (2009). Canadian Environmental Policy and Politics. Prospects for Leadership and Innovation. Oxford: Oxford University Press.

Voss, J.-P., Bauknecht, D., et al. (Eds.). (2006). Reflexive governance for sustainable development. Edward Elgar: Cheltenham.

Wapner, P. K. (1996). Environmental activism and world civic politics. Albany: State University of New York Press.

Young, O. R. (1999). Governance in world affairs. Ithaca, NY: Cornell University Press.

Young, O. R. (2002). The institutional dimensions of environmental change: Fit, interplay and scale. Cambridge, MA: MIT Press. 